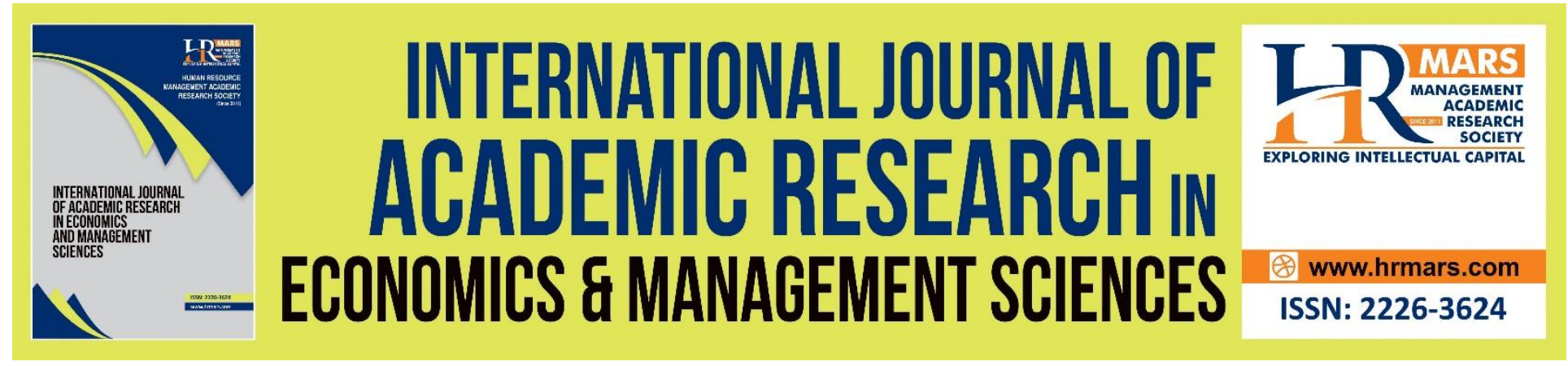

\title{
Enhancing Service Quality Through Good Governance Practice in Zakat Institution
}

\author{
Norsyella Ahmad Tamizi, Umi Hamidaton Mohd Soffian Lee, Nor Azima \\ Ahmad, Muhammad Hakimi Mohd Shafiai
}

To Link this Article: http://dx.doi.org/10.6007/IJAREMS/v10-i3/10184

DOI:10.6007/IJAREMS/v10-i3/10184

Received: 18 May 2021, Revised: 19 June 2021, Accepted: 08 July 2021

Published Online: 28 July 2021

In-Text Citation: (Tamizi et al., 2021)

To Cite this Article: Tamizi, N. A., Lee, U. H. M. S., Ahmad, N. A., \& Shafiai, M. H. M. (2021). Enhancing Service Quality Through Good Governance Practice in Zakat Institution. International Journal of Academic Research in Economics and Managment and Sciences, 10(3), 94-105.

Copyright: (C) 2021 The Author(s)

Published by Human Resource Management Academic Research Society (www.hrmars.com)

This article is published under the Creative Commons Attribution (CC BY 4.0) license. Anyone may reproduce, distribute, translate and create derivative works of this article (for both commercial and non-commercial purposes), subject to full attribution to the original publication and authors. The full terms of this license may be seen at: http://creativecommons.org/licences/by/4.0/legalcode

Vol. 10, No. 3, 2021, Pg. 94 - 105

http://hrmars.com/index.php/pages/detail/IJAREMS

JOURNAL HOMEPAGE

Full Terms \& Conditions of access and use can be found at http://hrmars.com/index.php/pages/detail/publication-ethics 


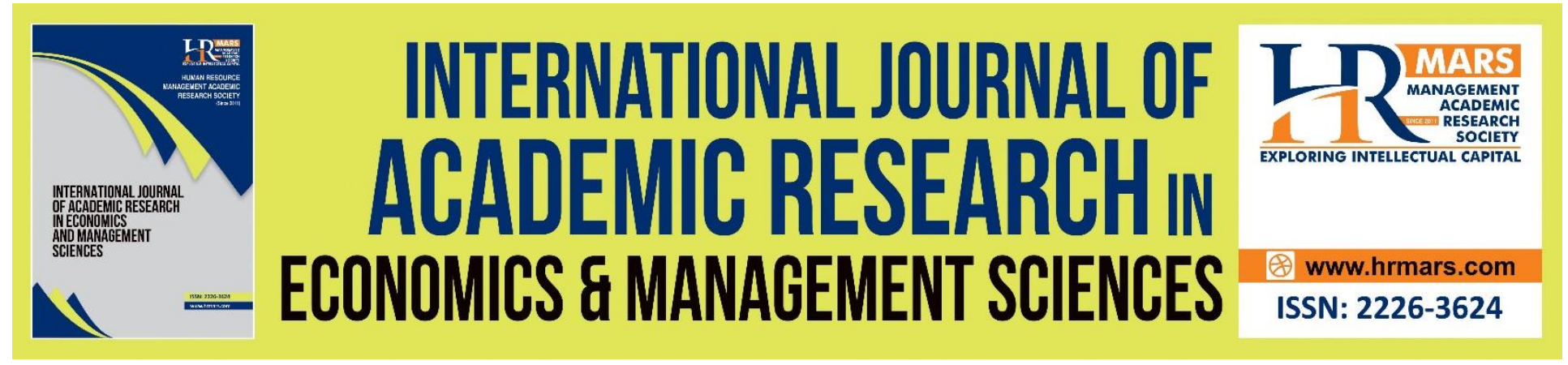

\title{
Enhancing Service Quality Through Good Governance Practice in Zakat Institution
}

\author{
Norsyella Ahmad Tamizi ${ }^{1}$ \\ Institut Islam Hadhari, Universiti Kebangsaan Malaysia, Pusat Islam, Universiti Sains Malaysia \\ Umi Hamidaton Mohd Soffian Lee ${ }^{2}$ \\ Faculty of Economics \& Muamalat, Universiti Sains Islam Malaysia.
}

\begin{abstract}
Nor Azima Ahmad ${ }^{3}$, Muhammad Hakimi Mohd Shafiai ${ }^{4}$
Institut Islam Hadhari, Universiti Kebangsaan Malaysia

Email: umihamidaton@usim.edu.my
\end{abstract}

\begin{abstract}
In the era of $4^{\text {th }}$ industrial revolution, good governance practise has become an important organizational management and administration practice for achieving organizational function and objectives especially in zakat institution. Nowadays, zakat institution became as a central role in many aspects of human life especially among Muslim communities, also function in maintaining the existence and growth of socio-economic. Due to this reason, good governance with the vital elements of leadership and communication are an important element that may affect service quality performance in organization. The capability of employees to appropriately manage leadership and communication practice may lead to a greater level of quality performance towards customers. This research aims to measure the correlation between good governance practice through leadership, communication, and service quality in zakat institution. A cross-sectional technique was employed to collect primary data from 250 respondents who were customer at the zakat institution in Klang Valley. The Partial Least Square Structural Equation Modelling (PLS-SEM) was used in data analyses. The outcomes displayed two important findings: First, the relationship between leadership practice and service quality performance was significant. Second, the relationship between communication practice and service quality performance was significant. Statistically, this result confirms that service quality performance directly enhanced by good governance practice through leadership and communication in studied organization. Further, this research concludes with a discussion on the contributions, limitation. For future research may focus on other elements of construct such as integrity practice to enhance service quality in zakat institution.
\end{abstract}

Keywords: Leadership, Communication, Good Governance, Service Quality, Zakat Institution. 


\section{Introduction}

In Arabic, zakat refers to a monetary religious obligation paid to the poor and needy categories (as stated in Al-Quran) by wealthy Muslims. The act of paying zakat has become an integral part of Islamic economic policies and fulfilment of Allah's commands. Zakat aims to create a fair distribution of wealth between wealthy and needy people aiming to alleviate poverty and reduce economic gaps (Abdulsalam \& Mustafa, 2021). Good governance has played an important role in zakat institution to ensure administration and management function of the institution reflects socio economic, moral, and spiritual development of Muslims societies besides it have huge impacts in achieving social harmony and preserving decent living standards for the poor and needy Muslim communities.

Governance of a zakat institution in this country is under the jurisdiction of respective State Islamic Religious Council (Hasanah et al., 2017). Each State Islamic Religious Council (MAIN) plays a vital role in zakat governance which involves the management, administration, collection and distribution of zakat funds to eight group of people who qualified as asnaf such as the poor, the needy, the slave who desires freedom, those who are in debt for basic expenditure, the stranded traveller, the revert or those who convert into Islam, those who strive in the way of Allah, and those who work in administrating zakat (Hairunnizam et al., 2017). The success of zakat in helping poor and needy was recorded throughout the early stage of Islam especially during the period of 'Umar ibn 'Abd al-'Azīz, ruler of Umayyad Caliph.

Recently, the amount of zakat collection is showing positive significance of increasing year by year, and it shows the trustworthy management of zakat institution had encouraged an excellent giving and charitable behaviour from Muslim communities (Abdulsalam, 2021; Adibah et al., 2014). The notable success of zakat performance and management during this period was possible related to good governance practice. Therefore, it is notable to highlight good governance practice in a zakat institution in order to ensure it is able to enhance service quality provided by zakat institutions towards customers. Service quality in zakat institution is important to attract Muslim communities' involvement in giving and caring behaviour through zakat due to its potential of boosting economic prosperity in Malaysia as one of contemporary Muslim counties.

\section{Good Governance in Zakat Organization}

The zakat institution is the main organization of the Muslim community to fulfill the Three Pillars of Islam. Zakat governance plays an important role in achieving the objectives of the organization. Therefore, to improve the quality of organizational services, good governance is an important role for the success of zakat institutions. Good governance is a work process, decision -making in a public entity to achieve organizational performance (Zurina et al., 2019). In the context of good zakat governance can reduce the problem of poverty among the Muslim community. In addition, with good governance can improve the economy of the Muslim community. While good governance can reduce bureaucracy in the organization and can increase accountability and transparency in the organization (Siddiquee, 2006).

Good governance is composed of two important elements namely leadership and communication because can give a significant contribution to the achievement of good governance (Nirmaljeet, 2015). In improving the commitment and quality of services provided in zakat institutions, it is necessary to focus on the elements of governance such as leadership and 
communication. These elements are able to provide positive changes in improving the quality of organizational services.

Good governance practice has been widely discussed by scholars and has been a focus in measuring the effectiveness of an organization service, outcome and performance which include service quality (Hafizah et al., 2016). Leadership is often viewed as a mechanism used by leaders to deals with employees or followers towards achieve organizational goals and target (Lussier \& Achua 2016; Umi et al. 2019; Yusniati Ishak 2018). Since employees come from different background with various job designation and task leaders need to engage with employees through action and behaviour which may influence the employee's outcome and performance which reflect the service quality provided towards public who seeking services from organization or institution. According to Soffian Lee et al., (2019); Ramesh et al., (2018) the increasing organizational performance is closely related to the employees' individual performance which can be achieved through the responsibility of the leader. Besides, according to Lutfan (2017), good governance is new scenario for leader to meet the demands of globalization more effectively, so zakat institutions must go through a transformation based on ISO (International Organization of Standardization) procedures to increase the quality of service offered to the community (Hairunnizam \& Sanep, 2014).

Leadership practice in zakat institutions mainly focus on the areas of zakat fund collection, distribution, and administration. Leadership leads employees needs to always be prepared and aware on the direct and indirect development and changes in governance especially within the current advancement of industrial revolution 4.0 to fulfil the objectives set by the organization. Thus, a leadership practice has ability to create awareness and always be ready for any situation and committed to implement needed changes in organization to increase the quality of services offered to the Muslim publics and communities (Sathiran et al., 2013; Hasanah et al., 2017; Norsyella et al., 2020). Leadership practices create an ability for employees in organization to master various skills and should be innovative to face the impending challenges of the global arena and to deal with the increasing workload and technological as well as climate changes of the organization (Mohamad et al., 2016; Lee et al., 2019).

Besides, communication according to Berret (2008) refers to process of transmitting meaning to another individual verbally or non-verbally. Effective communication is an essential skill to be possessed by members in governing an organization so that the goals and standards of the organization can be achieved and thus increasing the quality of service (Norsyella et al., 2020). Maizatul et al (2019) agreed that every employee in an organization needs to be equipped with effective communication skills. In zakat institution context, communication is an important element in governance because it may lead to enhance other aspects such as like efficiency, performance, trust, and zakat payment compliance (Luhur, 2016; Abdulsalam \& Mustafa, 2021). On the other hand, according to Yusri \& Hazlami (2015), communication also involve feedback from the customers to express their expectations, suggestion, and recommendation to improve the outcome of organization. Communication in good governance will provide clear information transmission, supervising, conveying directives, motivating and guiding the employees have positive impact on career development and lead to increasing the quality of the organizational productivity and services (Nirmaljeet, 2015; Azman et al., 2018)

Moreover, the attention and commitment of communities towards function of zakat institution may varies from one another due to different reasons and circumstances and it close related to 
good governance practise. However, the role of contemporary of zakat institution is said to be significance. Zakat institution is a subsector to a service that is important towards customer satisfaction. Hence, the satisfaction of the customers is used as a benchmark to the progress of the organization. Customer satisfaction on the services provided within zakat institutions signifies success in their organizational governance towards achieving the mission, vision and objectives set by the organization. Service quality is the outcome of the evaluation process conducted on customers based on their expectation on the services received (Safiek \& Fadhiha, 2019). Various measures have been taken to increase the service quality of zakat institutions to improve the perception of the community when the services offered are in accordance with service preparation and delivery of the organization. An organization is capable and successful when it can meet the demands of the customers with high quality service (Kamarulzaman et al., 2015). Furthermore, work quality through excellent work culture and practice in organization is very important to be emphasized to achieve a set standard of service quality (Masitah et al., 2019). Therefore, concerns over the lack of effective in-service quality of current zakat institution have encouraged researcher to investigate issues and challenge towards improving zakat institution function and performance. This situation encourages researchers to further explore the nature of the relationship between good governance practice (leadership and communication) and service quality. Specifically, this study intends to evaluate two major objectives: first, to examine the relationship between leadership and service quality. Second, to examine the relationship between communication and service quality.

\section{Literature Review}

\section{Good Governance through Leadership and Communication Enhancing Service Quality}

The role of good governance as an important predictor of service quality gained strong support from the notion of Social Exchange Theory (George, 1961, 1974; Blau, 1964, 1987). The notion of these theories is consistent with good governance practice research literature. Several recent studies were conducted using direct effect model to investigate the influence of good governance through leadership and communication towards service quality in various organization settings. For example, the perceptions of 24 respondents from education institution in Malaysia (Roselinda, 2015), 318 respondents from Universiti Kebangsaan Malaysia (UKM) Wan Idros et al. (2015), 86 respondents from educational institution in Kelantan (Fardaniah \& Salma, 2017), 150 respondents from Kolej Universiti Islam Selangor (KUIS), and perception of 1251 respondents from Universiti Utara Malaysia (UUM) (Fuad et al., 2020).

The finding of these surveys showed that the ability of good governance through leadership and communication will strongly enhance the service quality provided by the organization to customer wo seek services from zakat institution. Thus, it was hypothesized that:H1: There is positive relationship between leadership and service quality.

$\mathrm{H} 2$ : There is positive relationship between communication and service quality.

\section{Research Method}

Research Design

This study used a cross -sectional design which enables the researchers to integrate good governance literature and the actual survey as the main procedure for data collection and such method may lead researcher to gather accurate data, avoid elements of bias and can improve 
the quality of the data collected (Creswell, 2014; Sekaran \& Bougie, 2015). This study was conducted on respondents who were seeking services at the zakat institution in Klang Valley. This study aimed to provide empirical evidence of good governance practice by measuring the predicting variable of good governance in the zakat institution. Initially, the researcher prepared the questionnaire based on good governance literature. After that, a back translation technique was used to translate the survey questionnaire into English and Malay languages to improve understanding and to ensure the validity and reliability of research outcome (Creswell, 2008; Sekaran \& Bougie, 2010).

\section{Measures}

The survey questionnaire used in this study had three major sections: Firstly, leadership had seven items adapted from Yusof (2014); Roselena (2015); Baharuzaini (2016), communication had had eight items adapted from Idros \& Maizatul (2015); Che Su (2015) from good governance literature. Finally, service quality was measured using eight items adapted from service quality literature Fadilah et al (2014), Hawa et al., (2016) and Maryam et al (2018). The whole items were assessed using a 5-item scale ranging from "strongly disagree (1)" to "strongly agree (5)". Sample profile was treated as controlling variables because this research focused on respondent attitudes.

\section{Sample}

A purposive sampling plan was used to distribute 350 survey questionnaires to people who seek services from respected organization. From the total numbers, 250 (83.33\%) usable questionnaires were returned to the researchers. Participation in this study was voluntary, anonymous, and confidential.

\section{Data Analysis}

The SmartPLS 3.0 was employed to analyse the data collected from survey questionnaire because the capability to deliver latent variable was used to determine score, small sample size issues and estimate complex model (Hair et al., 2017; Henseler et al., 2009). There are several procedures of data analysis: first, confirmatory factor analysis was used to assess the validity and reliability of instruments. Second, SmartPLS path model used to test hypothesized model. If the value of $t$ statistic larger than 1.5 it clearly shows the significant relationship between independent variable and dependent variable (Henseler et al., 2009). Third, the value of R2 is used an indicator to identify predictive strength of the research model based on the value of: 0.19 (weak), 0.33 (medium) and 0.67 (substantial) (Hair et al., 2017; Henseler, 2009). Four, the value of $f 2$ was used as a measure to determine the effects size predicting variable in the mode; based on the rule of: 0.02 (weak), 0.15 (medium) and 0.35 (large) (Hair et al., 2017). Lastly, the value of Q2 for dependent variable higher than zero will prove that the model has predictive relevance (Hair et al., 2017).

\section{Findings}

Most respondents were women (68.4\%), aged from 20-25 years old, single (80.4\%), households earning RM3000 to RM5000 per month and use zakat services at the zakat counter (90.8\%).

In terms of reliability, the value of factor loading for each item for the leadership construct, communication and service quality were greater than 0.708 indicating that the construct model measurement had met its reliability criteria (Hair et al., 2017). The output value of the Variance Inflation Factor (VIF) between the independent variable (leadership and communication) and the 
INTERNATIONAL JOURNAL OF ACADEMIC RESEARCH ECONOMICS AND MANAGEMENT SCIENCES

Vol. 10, No. 3, 2021, E-ISSN: 2226-3624 ㄷ 2021 HRMARS

dependent variable (service quality) was lower than 5.0 indicating that the construct is free of serious collinearity problems (Hair et al., 2017).

The results of the reliability analysis are shown in Table 1 below:

Table 1: Factor loading and Variance Inflation Factor (VIF) Value

\begin{tabular}{|c|c|c|}
\hline Construct/ Items & $\begin{array}{l}\text { Factor } \\
\text { Loading } \\
>0.708\end{array}$ & $\begin{array}{l}\text { Variance Inflation Factor } \\
(\text { VIF })<5.0\end{array}$ \\
\hline $\begin{array}{l}\text { Leadership } \\
\text { KP1 Immediate action on feedback } \\
\text { KP2 Discuss professionally } \\
\text { KP3 Emotional control } \\
\text { KP4 Extensive knowledge in the scope of work } \\
\text { KP5 Polite and neat } \\
\text { KP6 Characteristics of leadership and mentoring } \\
\text { KP7 Counselling and advice services }\end{array}$ & $\begin{array}{l}0.793 \\
0.851 \\
0.838 \\
0.856 \\
0.820 \\
0.829 \\
0.838\end{array}$ & $\begin{array}{l}2.205 \\
2.889 \\
2.645 \\
2.760 \\
2.479 \\
2.675 \\
2.546\end{array}$ \\
\hline $\begin{array}{l}\text { Communication } \\
\text { KM1 Relevant feedback } \\
\text { KM2 Easy -to -understand language interaction. } \\
\text { KM3 Application of technology in dealing } \\
\text { KM4 Virtuous values while communicating. } \\
\text { KM5 Good listener } \\
\text { KM6 Good relationship with customers } \\
\text { KM7Comprehension of language and sentence } \\
\text { structure of websites, posters and so on. } \\
\text { KM8 Ease of internet access }\end{array}$ & $\begin{array}{l}0.788 \\
0.847 \\
0.794 \\
0.845 \\
0.822 \\
0.804 \\
0.829 \\
0.761\end{array}$ & $\begin{array}{l}2.128 \\
2.763 \\
2.165 \\
2.985 \\
2.683 \\
2.505 \\
2.647 \\
2.103\end{array}$ \\
\hline $\begin{array}{l}\text { Service Quality } \\
\text { KK1 Comply with the client's charter. } \\
\text { KK2 Good quality of work } \\
\text { KK3 Work efficiency } \\
\text { KK4 Comfortable space } \\
\text { KK5 Students are the main customers of the service. } \\
\text { KK6 Customer-friendly } \\
\text { KK7 Basic facilities } \\
\text { KK8 Immediate action }\end{array}$ & $\begin{array}{l}0.805 \\
0.820 \\
0.844 \\
0.781 \\
0.810 \\
0.806 \\
0.780 \\
0.830\end{array}$ & $\begin{array}{l}2.347 \\
2.383 \\
2.688 \\
2.141 \\
2.292 \\
2.216 \\
2.444 \\
2.727\end{array}$ \\
\hline
\end{tabular}

Table 2 shows the results of convergent and discriminant validity analysis. For studies using Smart-PLS software, for convergent validity, an Extracted Average Variance (AVE) value more than 0.5 indicates that the construct meets an acceptable level of convergent validity (Hair et al. 2017). Composite Reliability (CR) values for each construct greater than 0.70 indicate that internal consistency for the study instruments is high (Hair et al., 2017). Further, the Cronbach Alpha reliability coefficient is above 0.70 indicating that the instrument of this study has an acceptable reliability value (Bond \& Fox, 2015). Thus, these statistical results confirm that the construct has met the analytical standards of validity and reliability. 
Table 2: Validity and Reliability Analysis

\begin{tabular}{|l|l|l|l|}
\hline CONSTRUCT & \multicolumn{1}{|c|}{ AVE } & \multicolumn{2}{c|}{ CA } \\
\hline Leadership & 0.693 & 0.940 & 0.693 \\
\hline Communication & 0.659 & 0.939 & 0.659 \\
\hline Quality Service & 0.656 & 0.938 & 0.656 \\
& & & \\
\hline
\end{tabular}

\section{Structural Model Analysis}

\section{Hypothesis Results}

To measure the strength of the structural model is to refer to level $\mathrm{R}^{2}$. For studies related to social behaviour, the recommended $R^{2}$ value is $R^{2}=0.67$ categorized as strong, 0.33 as moderate and 0.19 as weak (Chin 1998; Hair et al., 2014; Henseler et al., 2009). Figure 1 shows the effect of effective leadership and communication practices on work quality is $89.8 \%$. These results indicate that leadership and communication contribute high impacts for the study model (Hair et al., 2017; Henseler, 2010). Whereas, for the hypothesis, the Smart-PLS path coefficient has shown that leadership has a positive relationship with service quality $(\beta=0.540 ; t=5.740, p=0.000)$, $\mathrm{H} 1$ is accepted. Second, communication was positively correlated with service quality $(\beta=0.422$, $t=4.420, p=0.000)$. Therefore, $\mathrm{H} 2$ is supported. These results suggest that both construct acts as an important predictor of service quality.

Figure 1: Result of Testing Direct Effects Model

\begin{tabular}{|c|c|c|}
\hline \multicolumn{1}{|l|}{\begin{tabular}{|c|} 
Independent Variable \\
Leadership
\end{tabular}} & $\begin{array}{c}\text { Dependent Variable } \\
R^{2}=89.8 \%\end{array}$ \\
\hline Communication & $(\beta=0.540 ; t=5.740)$ & Service Quality \\
\hline & & \\
\hline
\end{tabular}

Note: Significant at $t>1.65$ (one tail testing)

Bootstrapping and blindfolding procedures were performed to measure the impact size ( $f 2$ ) and the relevance of the PLS forecast (Q2). The effect size (f2) in the study model based on the criteria proposed by Hair et al. (2017) and Henseler (2010) namely 0.02 (weak), 0.15 (moderate), 0.35 (strong). The results of the effect size test ( $f 2$ ) showed that leadership gave a moderate effect of 0.335 . Meanwhile, the value of $\mathrm{f} 2$ for communication showed a moderate effect of 0.204 . In addition, additional analysis was conducted to test the PLS prediction (PLS Predict) PLS prediction test results of the reflective latent variable showed that Q2 for service quality was greater than zero 0.579 indicating that this construct had predictive relevance (Hair et al. 2017). A summary of the hypothesis results is shown in the table below. 
INTERNATIONAL JOURNAL OF ACADEMIC RESEARCH ECONOMICS AND MANAGEMENT SCIENCES Vol. 10, No. 3, 2021, E-ISSN: 2226-3624 @ 2021 HRMARS

Table 3: Structural Model Analysis

\begin{tabular}{|l|l|l|l|l|l|l|}
\hline & $\mathrm{B}$ & $t$-stat & $p$-value & $\mathrm{f}^{2}$ & $\mathrm{R}^{2}$ & $\mathrm{Q}^{2}$ \\
\hline $\begin{array}{l}\mathrm{H} 1: \text { There is positive relationship } \\
\text { between leadership and service quality. }\end{array}$ & 0.540 & 5.740 & 0.000 & 0.335 & & \\
\hline $\begin{array}{l}\mathrm{H} 2: \text { There is positive relationship } \\
\text { between communication and service } \\
\text { quality. }\end{array}$ & 0.422 & 4.420 & 0.000 & 0.204 & 0.579 \\
\hline
\end{tabular}

\section{Discussion and Implications}

This study proves that governance (leadership and communication) is an important predictor to service quality. Organizational governance implemented effectively according to the development and need of customers can improve the service quality offered by the organizations. Furthermore, there are several other factors that influence service quality including work environment and support practices within an organization.

The implications of this study can be divided into three main aspects which include theoretical, methodological, and practical (organization) contributions. Theoretically, this study proves that Social Exchange Theory is consistent with the result. Employees who receive prominent and efficient support will in turn show a positive working attitude on this matter, organizational commitment, and organizational citizenship.

Future studies on this specific matter are recommended to explore the extent of organizational support in influencing other constructs such as job satisfaction, and quality and performance of the employees. The methodology used in this study shows that the use of survey questionnaire can provide a deeper insight on the study where the selected instrument exceeds the minimum standards for validity and reliability thus producing accurate findings. Practically, this study opens opportunity to organizations and management teams to identify and practice effective governance to ensure the increase of service quality and to achieve their main objectives.

Previous studies on this matter mostly discussed the level of service quality with government and corporate organizations compare to non-profit organization. It was found that there was a huge disparity in their goals for quality service based on their objective towards profit. Zakat institution on the other hand, may increase their service quality by focusing on governance efficiency in collecting, distributing, and administering zakat fund (Hairunnizam et al., 2017) A good governance will be a positive impact to the organization by provided services customers satisfaction (Fadilah, 2014). Indirectly, management will also identify the dimension of poor governance from by customer feedback.

A good governance at zakat institution will enable to achieve the objectives, vision and mission. In addition, the factor to attract a positive impression of the organization the feedback from customer will be improve the services offered to study research. While the contribution to the consolidation of research methods, this analysis shows the item arrange on validity and reliability lever in research instrument, so the results this research can use as a guide to other organizations specially governance organization. To improve the quality service, zakat institution can give training for employees focus to service quality about objective of zakat organization. This 
proposal will be considered as well as the customer's confidence able to support the real purpose of the zakat organization.

\section{Conclusion}

This study verifies that leadership and communication are important variables in increasing service quality. This study also shows that systematic and effective governance in an organization can facilitate the employees to increase the quality of services provided to the clients and customers. Therefore, the increase of organizational service quality will enable the organizations to continue to grow and remain competitive in this modern globalization era. Islam also emphasizes that quality of service is an element to taken seriously as mentioned in Surah atTawbah verse 105 which means "And tell them, (O Prophet), work (righteousness) and Allah with behold your works and so will His Messenger and believers". Thus, in line with the recommendation of Islam, quality in service can be achieved by performing our tasks as an individual and together as an organization with confidence for Allah is always watching every deed that we do. Additionally, the measurement on certain level of quality needs to be considered based on the distinctive nature of the service provided (Parasuraman et al., 1985).

The hypothesis is based on the result of service decisions and the instrument has achieved high validity and reliability. The findings of the research, leadership, and communication element can increase customer's satisfaction. As a result, show a positive impact about organizational and enhancing the services quality competition between all organizational and performance in era global economy. This factor can give a positive impression of organizational governance. In conclusion, this study suggests this element will be improvement of organization services and attract customers to achieve organizational goals.

\section{Reference}

Abdulsalam, A. S., \& Mustafa, O. M. (2021). How governance practice influences mandatory zakat payment in Saudi Arabia? Journal of King Abdul Aziz: Islamic Economics, 34 (1), 3-2.

Abd Wahab, N., \& Abdul Rahman, A. R. (2011). Efficiency of zakat institutions and its Determinants. 8th International Conference on Islamic Economics and Finance Efficiency, 119.

Adibah, A. W., \& Joni, T. B. (2014). Faktor penentu pembayaran zakat oleh entiti perniagaan di Malaysia: Satu tinjauan teori. Jurnal Syariah, 22(3), 295-322.

Fuad, A. M. H., Faiz, K. A., Hishamudin, I., \& Mashetoh, A. M. (2020). Amalan kesantunan berbahasa dalam komunikasi formal dan tidak formal dalam kalangan pelajar universiti. Malaysia Journal of Communication, 36(4), 410-427.

Azman, I., Azmi, N. M. Z., \& Nisak, N. A. (2016). Program pembangunan kepimpinan meningkatkan pemindahan latihan dalam tentera darat Malaysia: Kajian empirikal. Jurnal Pengurusan, 46,149- 161

Baharuzaini, B., Hisham, M. A., Hanif, M. Z., Hisyam, K. M., \& Norhaini, A. M. (2016). Gaya kepimpinan guru besar dan tahap efikasi guru. Journal of Personalized Learning, 2(1), 9-17.

Barrett, D. J. (2008). Leadership Communication. McGraw-Hill. New York

Cadbury, A. (2000). The corporate governance agenda. Corporate Governance, 8(1), 7-15

Che Su, M. (2015). Kompetensi komunikasi dan kepuasan komunikasi penjawat awam di Malaysia. Jurnal Pengurusan, (43),13-26 
Enida, D. (2018). Perlaksanaan konsep masuliyyah dalam tadbir urus pihak berkuasa tempatan bagi memastikan sistem penyampaian perkhidmatan yang cekap dan berkesan. Journal of Human Capital Development, 11 (2), 1985-7012

Fadilah, M. N., Safura, A. S., \& Khairuddin, K. (2014). Tahap kepuasan pelanggan terhadap kualiti perkhidmatan pengangkutan awam di KUIS. Proceeding of the 1st International Conference on Management and Muamalah (1st ICoMM)

Hafizah, Z., Azizi, A. B., \& Ram, A. J. S. (2016). Reputation, satisfaction of zakat distribution and service quality as determinant of stakeholder trust in zakat institution. International Journal of Economics and Financial Issues, 6 (7), 72-76.

Hairunnizam, W., \& Sanep, A. (2014). Faktor mempengaruhi tahap keyakinan agihan zakat: kajian terhadap masyarakat Islam di Selangor. Jurnal Ekonomi Malaysia, 48 (2), 41-50

Hairunnizam, W., Sanep, A., Ali, M. N., \& Maryam, R. (2017). Prestasi kecekapan pengurusan kewangan dan agihan zakat: perbandingan antara Majlis Agama Islam Negeri di Malaysia. Jurnal Ekonomi Malaysia, 51 (2), 39-54

Hairunnizam, W., Sanep, A., \& Radiah, A. K. (2009). Pengagihan zakat oleh institusi zakat di Malaysia: mengapa masyarakat Islam tidak berpuas hati?. Jurnal Syariah, 17(1), 89-112

Ishak, Y., Ismail, A., Samsudin, A., Lee, M. S. U. H., Ali, M. H. (2018). Human-oriented leadership and encouragement to perform work: modelling organizational attachment as mediator. Jurnal Pengurusan, 54, $39-50$

Kamarulzaman, M., Azman, N. M. A., \& Mahadzirah, M. (2015). Kualiti perkhidmatan, kepuasan pelanggan dan kesetiaan pelanggan perbadanan perpustakaan awam terengganu: kajian konseptual. Journal of Malaysian Librarians, 9.

Wicaksono, L. (2016). Bahasa dalam komunikasi pembelajaran. Journal of Prospective Learning, $1(2), 9-19$

Lussier, R. N., \& Achua, C. F. (2016). Leadership Theory, Application \& Skill Development. United States: Cencage Learning.

Lutfan, J., Fadillah, I., Akmal, Z. D., Zuhaila, A., \& Zainal, A. (2017). Cabaran tadbir urus universiti awam masa kini. Seminar Khas Kelestarian Perkhidmatan Awam.

Maizatul, H. M., Syakira, N. A. M. A., Idros, W. S., \& Amizah, W. M. (2019). Komunikasi strategi dan peranannya untuk mewujudkan komunikasi berkesan dalam organisasi. Malaysia Journal of Communication, 35 (2), 49-67.

Maryam, A. R. Hairunnizam, W., \& Sanep, A. (2018). Analisis faktor penentu kualiti pengurusan zakat: kajian terhadap Lembaga Zakat Selangor (LZS) Di Sepang. Journal of Fatwa Management and Research.

Nirmaljeet, S. K. (2015). A strategic framework for a good governance through e- governance optimization. Program Electronic library and Information Systems, 49 (2), 170-204

Nordin, N., \& Hassan, M. M. (2019). Faktor-faktor yang mempengaruhi komitmen prestasi kerja dalam kalangan penjawat awam. Kajian rintis di jabatan kemajuan masyarakat, negeri Pulau Pinang. Malaysia Journal of Social Sciences and Humanities, 4 (7)

Norsyella, A. T., Soffian, M., Lee, U. H., Aimi, A., \& Hakimi, M. S. (2020). Perhubungan amalan tadbir urus terhadap kualiti perkhidmatan. Kertas konseptual. Prosiding Seminar Penyelidikan Siswazah. Selangor: Universiti Kebangsaan Malaysia.

Parasuraman, A., Zeithmal, V., \& Berry, L. (1985). A conceptual model of service quality and its implications for future research. Journal of Marketing, 49(4), 41-50. 
Parasuraman, A., Zeithaml, V. A., \& Berry, L. L. (1988), Servqual: A multiple-item scale for measuring consumer perc. Journal of Retailing, 64 (1),12-40.

Patmawati, H. I. (2008). Pembangunan ekonomi melalui agihan zakat: Tinjauan empirikal. Jurnal Syariah, 16 (2), 223-244

Roslinda, Y. (2014). Ciri-ciri kepimpinan, pelajar pintar dan berbakat: implikasi ke atas kepimpinan remaja Islam. International Journal of Islamic Thought, 6

Roselinda, M. (2015). Kepimpinan berkualiti: perspektif mengenai kompetensi yang diperlukan untuk memimpin dengan berkesan. Jurnal Pengurusan, 45, 143-154

Safiek, M., \& Fadhiha, N. M. (2019). Hubungan antara kualiti perkhidmatan, kepuasan dan kesetiaan pelanggan dalam industri taska. Journal of Business Innovation. 4(1), 13-22

Samaratunge, R., Alam, Q., \& Teicher, J. (2008). The new public management reforms in Asia: A comparison of South and Southeast Asian countries. International Review of Administrative Sciences, 74 (1), 25-46.

Santhidran, S., Chandran, V. G. R., \& Borromeo, J. (2013). Enabling organizational change, leadership, commitment to change and the mediating role of change readiness. Journal of Business Economics \& Management, 14(2), $348-363$

Siddiquee, N. A. (2006). Public management reform in Malaysia: Recent initiatives and experiences. International Journal of Public Sector Management, 19 (4), 339-358

Siti Fardaniah, A. A., \& Salma, C. M. (2017). Pengaruh kepimpinan transformasi, keberkesanan latihan dan kualiti kehidupan bekerja terhadap kualiti perkhidmatan guru di Malaysia. Journal of Social Sciences and Humanities, 3

Siti Hawa, R. E., Haliyana, T., Raudhiah, N. A. B., Azharuddin, H., \& Afizan, A. (2016). Penilaian kualiti perkhidmatan bagi penerima bantuan skim zakat asnaf mualaf di institusi pemberi zakat. Journal of Business Innovation, 1(2), 81-102

Sureshchandar, G. S., Rajendran, C., dan Anantharaman, R. N. (2002). Determinants of customerperceived service quality: a confirmatory factor analysis approach. Journal of Services Marketing, 16(1), 9-34

Wan Idros, W. S., \& Maizatul, H. M. (2015). Hubungan komunikasi keorganisasian dengan perancangan strategik modal insan universiti kebangsaan malaysia. Malaysian Journal of Communication, 31(2),1-14

Zeithaml, V. A., Bitner, M. J., \& Gremler, D. D. (2017). Services marketing. Integrating customer focus across the firm, (7th. Ed.). New York: McGraw-Hill Irwin

Zelhuda, S., Abdul Ghafar, I., \& Bayu, T. P. (2014). Penilaian Teoretikal Terhadap Ciri-Ciri Tadbir Urus Di Kalangan Lembaga Pengarah Koperasi Di Malaysia. Proceeding of the 1st International Conference on Management and Muamalah 2014 (1st ICoMM) 